Wenfeng Li, Suping Li* and Xiangchong Zhong

\title{
Comparing the influence of different kinds of zirconia on properties and microstructure of $\mathrm{Al}_{2} \mathrm{O}_{3}$ ceramics
}

\begin{abstract}
This paper compared the influence of fused zirconia-corundum (AZ40), monoclinic zirconia $\left(\mathrm{m}-\mathrm{ZrO}_{2}\right)$, and $3 \mathrm{~mol} \%$ yttria-stabilized zirconia $\left(3 \mathrm{Y}-\mathrm{ZrO}_{2}\right)$ on physical properties at room temperature, hot modulus of rupture, and thermal shock resistance of $\mathrm{Al}_{2} \mathrm{O}_{3}$ ceramics, and their relationships with microstructure changes were investigated. It was found that $\mathrm{m}-\mathrm{ZrO}_{2}$ or $3 \mathrm{Y}-\mathrm{ZrO}_{2}$ addition promoted the process of sintering densification and enhanced the room temperature strength and the hot modulus of rupture of $\mathrm{Al}_{2} \mathrm{O}_{3}$ ceramics, and the effect of the latter was more distinct, while those of the sample with AZ40 addition decreased. In addition, the three kinds of $\mathrm{ZrO}_{2}$ were beneficial to improving the thermal shock resistance of $\mathrm{Al}_{2} \mathrm{O}_{3}$ ceramics. All these changes had close relationships with the changes of corresponding microstructure characteristics (including distribution of particles, degree of contact between crystals, grain boundary solid solution, microcrack density) and phase composition.
\end{abstract}

Keywords: $\mathrm{Al}_{2} \mathrm{O}_{3}$ ceramics; hot modulus of rupture; microstructure; phase composition; thermal shock resistance; $\mathrm{ZrO}_{2}$.

DOI 10.1515/secm-2014-0232

Received July 19, 2014; accepted September 28, 2014; previously published online December 22, 2014

\section{Introduction}

Alumina $\left(\mathrm{Al}_{2} \mathrm{O}_{3}\right)$ is considered as one of the most interesting ceramic candidates regarding its high melting point and excellent mechanical properties, such as high hardness, good chemical and thermal stability [1]. However, the application of $\mathrm{Al}_{2} \mathrm{O}_{3}$ ceramics is limited by their inherent brittle nature, which often leads to catastrophic

*Corresponding author: Suping Li, School of Materials Science and Engineering, Zhengzhou University, Zhengzhou 450052, China, e-mail: lisupinghtci@gmail.com

Wenfeng Li and Xiangchong Zhong: School of Materials Science and Engineering, Zhengzhou University, Zhengzhou 450052, China failure, especially under impact and tensile stress conditions $[2,3]$. One of the methods to improve this property is by introducing a moderate quantity of $\mathrm{ZrO}_{2}$ into $\mathrm{Al}_{2} \mathrm{O}_{3}$ ceramics; the mechanism of this process is based on the stress-induced phase transition from tetragonal zirconia $\left(\mathrm{t}-\mathrm{ZrO}_{2}\right)$ to monoclinic zirconia $\left(\mathrm{m}-\mathrm{ZrO}_{2}\right)$ [4-8]. Thus, the dispersion of $\mathrm{ZrO}_{2}$ in $\mathrm{Al}_{2} \mathrm{O}_{3}$ matrix results in a $\mathrm{Al}_{2} \mathrm{O}_{3} / \mathrm{ZrO}_{2}$ composite with higher hardness, elastic modulus, high temperature mechanical properties, and heat-shock property, and it is mainly used as cutting tools, bearings, hightemperature gas burner, knee replacement prostheses, and so on $[9,10]$.

Fused zirconia-corundum is one of the important $\mathrm{ZrO}_{2}$-containing materials, which contains a typical eutectic microstructure. Composites with a stoichiometry close to the eutectic point of around $40-42 \mathrm{wt} . \% \mathrm{ZrO}_{2}$ are found to exhibit excellent thermal stability and mechanical properties [11-13]. Some reports have pointed out that when the $\mathrm{ZrO}_{2}$ contains $3 \mathrm{~mol} . \% \mathrm{Y}_{2} \mathrm{O}_{3}$, the partially stabilized $\mathrm{ZrO}_{2}$ possesses excellent strength and fracture toughness $[14,15]$.

In this work, fused zirconia-corundum, $3 \mathrm{~mol} \% \mathrm{Y}_{2} \mathrm{O}_{3}$ stabilized $\mathrm{ZrO}_{2}$, and $\mathrm{m}-\mathrm{ZrO}_{2}$ were introduced into $\mathrm{Al}_{2} \mathrm{O}_{3}$ ceramics. The purpose was to compare the influence of them on physical properties at room temperature, hot modulus of rupture, and thermal shock resistance of $\mathrm{Al}_{2} \mathrm{O}_{3}$ ceramics, and their relationships with microstructure changes (including distribution of particles, degree of contact between crystals, grain boundary solid solution, microcrack density) and phase composition were discussed.

\section{Materials and methods}

\subsection{Starting materials and sample preparation}

The starting materials used in the present work were fused zirconia-corundum with its chemical composition of $59.4 \% \alpha-\mathrm{Al}_{2} \mathrm{O}_{3}-33.2 \% \mathrm{~m}-\mathrm{ZrO}_{2}-7.4 \% \mathrm{t}-\mathrm{ZrO}_{2}$ (denoted 
as AZ40, $\leq 7 \mu \mathrm{m}), 3 \mathrm{~mol} \%$ yttria-stabilized zirconia with its chemical composition of $76.2 \% \mathrm{t}-\mathrm{ZrO}_{2}-23.8 \%$ $\mathrm{m}-\mathrm{ZrO}_{2}$ (marked as $3 \mathrm{Y}_{-} \mathrm{ZrO}_{2}, \leq 7 \mu \mathrm{m}$ ), monoclinic zirconia $\left(\mathrm{ZrO}_{2} \geq 99.0 \%, \leq 7 \mu \mathrm{m}\right)$, and white fused corundum $\left(\alpha-\mathrm{Al}_{2} \mathrm{O}_{3} \geq 98.5 \%, \leq 44 \mu \mathrm{m}\right)$. The mass ratio of $\alpha-\mathrm{Al}_{2} \mathrm{O}_{3}$ to $\mathrm{ZrO}_{2}$ was $85 / 15, \mathrm{ZrO}_{2}$ was introduced into $\mathrm{Al}_{2} \mathrm{O}_{3}$ ceramics in forms of $\mathrm{AZ40}, \mathrm{m}-\mathrm{ZrO}_{2}$, and $3 \mathrm{Y}-\mathrm{ZrO}_{2}$, denoted as $\mathrm{Z}_{1}, \mathrm{Z}_{2}$ and $Z_{3}$, respectively, and the sample without $\mathrm{ZrO}_{2}$ addition was marked as $Z_{0}$. These materials were weighed in terms of this mass ratio and mixed for $1 \mathrm{~h}$ in a polyurethane bottle with water and zirconia balls, then pressed at $150 \mathrm{MPa}$ into samples with sizes of $180 \mathrm{~mm} \times 15 \mathrm{~mm} \times 15 \mathrm{~mm}$ and $\varnothing 36 \mathrm{~mm} \times 36 \mathrm{~mm}$, and sintered in air. The thermal profile was a ramp of $7^{\circ} \mathrm{C} / \mathrm{min}$ to $1100^{\circ} \mathrm{C}, 2^{\circ} \mathrm{C} / \mathrm{min}$ to $1200^{\circ} \mathrm{C}$, and followed by a ramp of $3^{\circ} \mathrm{C} / \mathrm{min}$ to $1650^{\circ} \mathrm{C}$, held for $3 \mathrm{~h}$.

\subsection{Sample characterization}

Bulk density and apparent porosity were measured using Archimedes' principle in water medium. Permanent linear change was examined by measuring the change in length of samples before and after firing. The modulus of rupture at room temperature and at $1400^{\circ} \mathrm{C}$ were determined by the standard three-point bending method. Cold crushing strength was measured using a hydraulic press machine in accordance with ISO 10059-1:1992. In thermal shock tests, the samples were heated to $1100^{\circ} \mathrm{C}$ and then quickly quenched in air. After three thermal shock cycles, the residual strength $\left(\sigma_{\mathrm{r}}\right)$ was measured and compared with the original strength $\left(\sigma_{\mathrm{f}}\right)$. Residual strength ratio $\left(\sigma_{\mathrm{r}} / \sigma_{\mathrm{f}}\right)$ at $\Delta \mathrm{T}=1100^{\circ} \mathrm{C}$ was a criterion for evaluating thermal shock resistance.

The phase contents were conducted using Philips X-ray diffractometer (XRD) with $\mathrm{Cu}$ Ka radiation $(\lambda=1.5406 \AA)$ in the $2 \theta$ range of $20-80^{\circ} \mathrm{C}$ for a period of $3^{\circ} / \mathrm{min}$ in the step scan mode. Microstructure and composition of samples were investigated by scanning electron microscopy (SEM, JEOL JSM-5610LV) equipped with an energy-dispersive spectrometry (EDS).

\section{Results and discussion}

\subsection{Physical properties at room temperature}

The permanent linear change, apparent porosity, and bulk density of samples are listed in Table 1, showing that the addition of $\mathrm{m}-\mathrm{ZrO}_{2}$ or $3 \mathrm{Y}-\mathrm{ZrO}_{2}$ can promote the process of sintering densification, while AZ40 addition results in a
Table 1 Permanent linear change, apparent porosity and bulk density of samples.

\begin{tabular}{lrrrr}
\hline Sample & $\mathbf{Z}_{\mathbf{0}}$ & $\mathbf{Z}_{1}$ & $\mathbf{Z}_{\mathbf{2}}$ & $\mathbf{Z}_{\mathbf{3}}$ \\
\hline Permanent linear change (\%) & -3.91 & +3.80 & -4.90 & -6.85 \\
Apparent porosity (\%) & 28.27 & 40.89 & 25.60 & 22.29 \\
Bulk density $\left(\mathrm{g} / \mathrm{cm}^{3}\right)$ & 2.95 & 2.40 & 3.08 & 3.23 \\
\hline
\end{tabular}

volume expansion and reduces the densification of $\mathrm{Al}_{2} \mathrm{O}_{3}$ ceramics.

Figure 1 shows the microstructures of samples $Z_{0}, Z_{2}$, and $Z_{3}$. In contrast to samples $Z_{2}$ and $Z_{3}$, the SEM photograph of the $\mathrm{Al}_{2} \mathrm{O}_{3}$ sample shown in Figure $1 \mathrm{~A}$ has a microstructure with coarse grains and large gaps, indicating a weak interface between crystals. For the sample with $\mathrm{m}-\mathrm{ZrO}_{2}$ or $3 \mathrm{Y}-\mathrm{ZrO}_{2}$ addition (see Figure $1 \mathrm{~B}$ and $\mathrm{C}$, respectively), the presence of the two distinct phases, $\mathrm{Al}_{2} \mathrm{O}_{3}$ (darker phase) and $\mathrm{ZrO}_{2}$ (brighter phase), can clearly be observed. It is clear that $\mathrm{ZrO}_{2}$ particles are homogeneously distributed in corundum skeleton structure inhibiting abnormal grain growth of $\mathrm{Al}_{2} \mathrm{O}_{3}$ and leading the dense structure.

The micrograph of the AZ40 starting material shown in Figure $2 \mathrm{~A}$ is a typical eutectic microstructure, which is made up of faceted colonies with a size of around 10-15 $\mu \mathrm{m}$ that consist of ordered $\mathrm{ZrO}_{2}$ phases within the $\mathrm{Al}_{2} \mathrm{O}_{3}$ matrix. When it is introduced into $\mathrm{Al}_{2} \mathrm{O}_{3}$ ceramics and sintered at $1650^{\circ} \mathrm{C}$ for $3 \mathrm{~h}$, the eutectic microstructure no longer exists, which is substituted by the microstructure that consists of coarse $\mathrm{ZrO}_{2}$ particles within the $\mathrm{Al}_{2} \mathrm{O}_{3}$ matrix, as shown in Figure 2B. The grown $\mathrm{ZrO}_{2}$ particles cannot be suppressed by $\mathrm{Al}_{2} \mathrm{O}_{3}$ matrix, t-phase has transformed spontaneously to m-phase during the cooling process. This is supported by the XRD pattern shown in Figure 4A; it can be seen that there is few $\mathrm{t}-\mathrm{ZrO}_{2}$ in the sample. The phase transformation of these grown $\mathrm{t}-\mathrm{ZrO}_{2}$ particles are accompanied by the volume expansion and crack formation, as shown in Figure $2 \mathrm{C}$, which leads to a decrease in the density of $\mathrm{Al}_{2} \mathrm{O}_{3}$ ceramics.

Cold crushing strength and modulus of rupture of samples are shown in Figure 3. As Figure 3 shows, $\mathrm{m}-\mathrm{ZrO}_{2}$ or $3 \mathrm{Y}-\mathrm{ZrO}_{2}$ addition is beneficial to improving the room temperature strength of $\mathrm{Al}_{2} \mathrm{O}_{3}$ ceramics, and the effect of the latter is more distinct, while those of the sample with AZ40 addition decrease.

The improvement of the room temperature strength of samples is primarily attributed to the stress-induced phase transformation toughening and the enhancement of density. Through XRD analysis on the surfaces of samples, as shown in Figure 4, monoclinic peaks at the (111) and (111) planes and tetragonal peak at the (111) plane of $\mathrm{ZrO}_{2}$ 

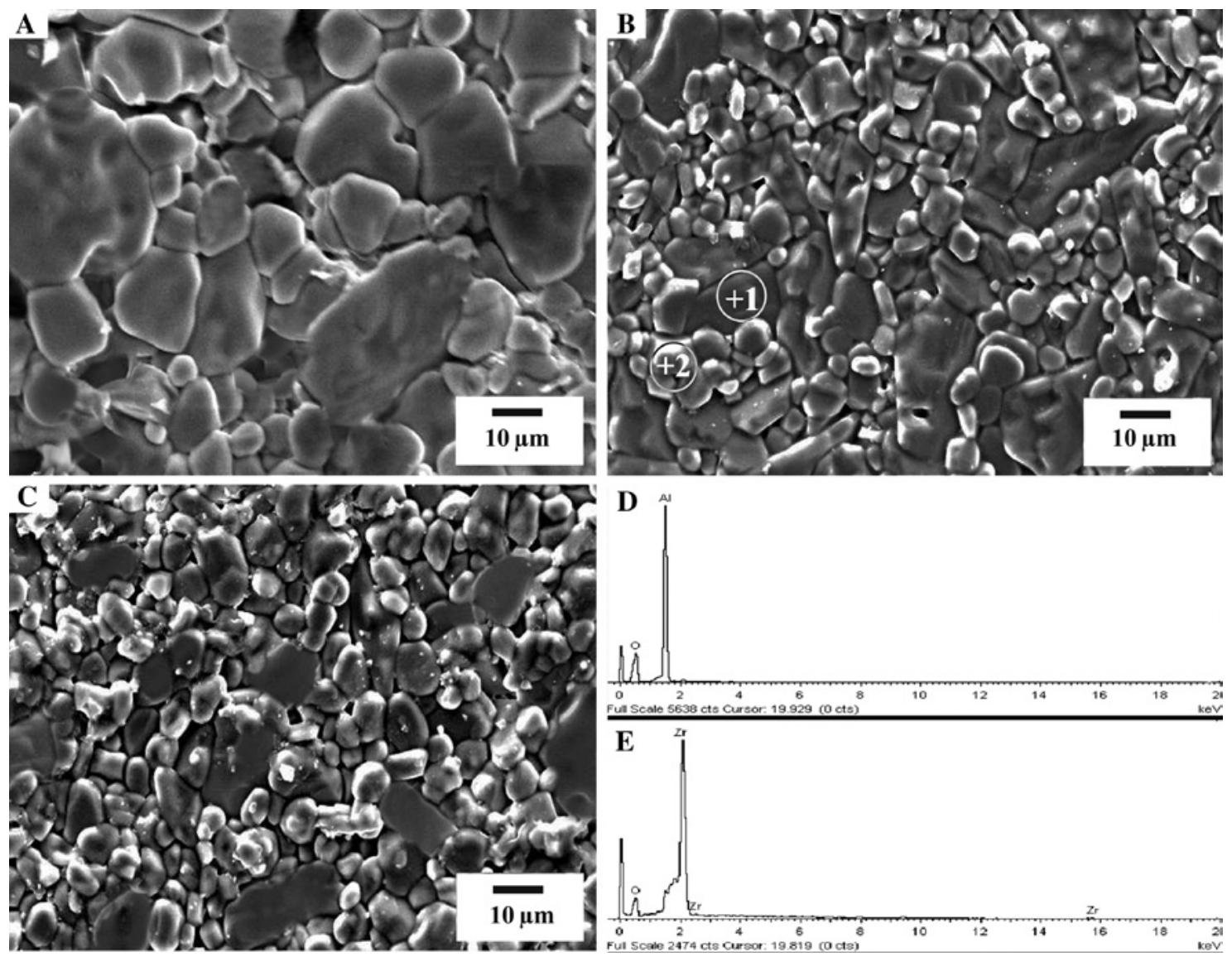

Figure 1 SEM photographs of samples (A) $Z_{0},(B) Z_{2},(C) Z_{3}$, (D) and (E) EDS spectrum of scanned sites 1 and 2 in (B), respectively.

are detected; the amount of $\mathrm{t}-\mathrm{ZrO}_{2}$ in samples is evaluated using Eq. (1) and Eq. (2) below [16]:

$$
\begin{gathered}
X_{m}=\frac{I_{m}(111)+I_{m}(11 \overline{1})}{I_{m}(111)+I_{m}(11 \overline{1})+I_{t}(111)} \\
X_{t}=1-X_{m}
\end{gathered}
$$

Here, $X$ is the relative content in the sample, $I$ is the absolute intensity, and the subscripts $m$ and $t$ refer to the monoclinic and the tetragonal phase, respectively.
For the sample with $3 \mathrm{Y}^{-} \mathrm{ZrO}_{2}$ addition, the amount of $\mathrm{t}-\mathrm{ZrO}_{2}$ is calculated and found to be $12 \%$ and $5 \%$ on the fracture face before and after sample failure, respectively, indicating that a portion of $\mathrm{t}-\mathrm{ZrO}_{2}$ has transformed into $\mathrm{m}$-phase during the modulus of rupture test, the crack propagation can be prevented by compressive stress due to this stress-induced phase transformation. In addition, the sample with $3 \mathrm{Y}-\mathrm{ZrO}_{2}$ addition has a dense structure. All these are important strengthening effects contributing to improvement of the room temperature strength of
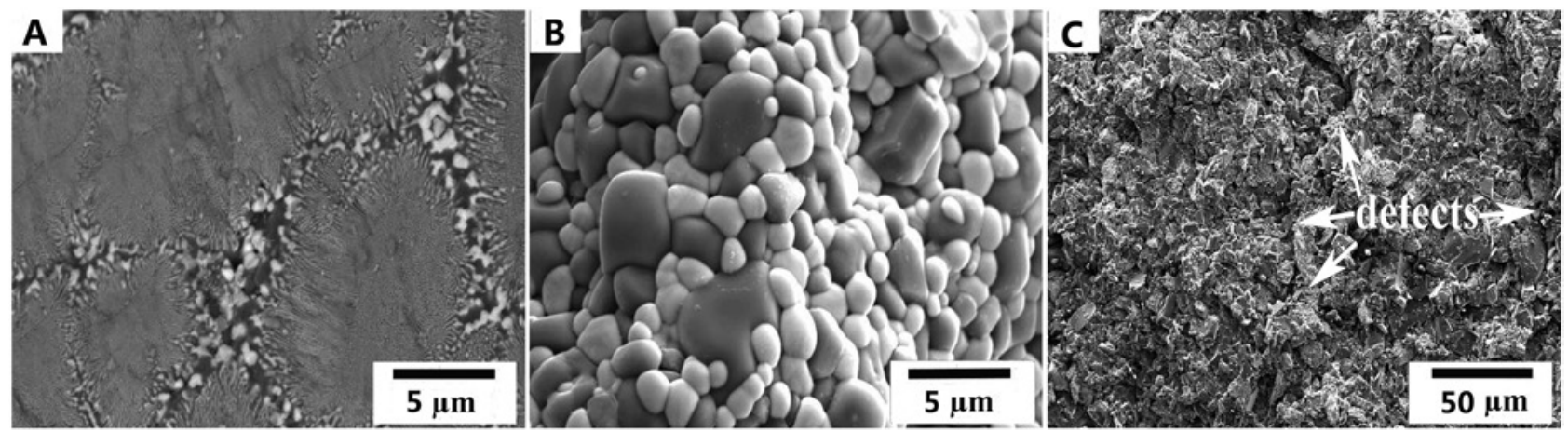

Figure 2 SEM photographs of (A) AZ40 starting material, (B) AZ40 after $3 \mathrm{~h}$ at $1650^{\circ} \mathrm{C}$, (C) the sample with AZ40 addition. 


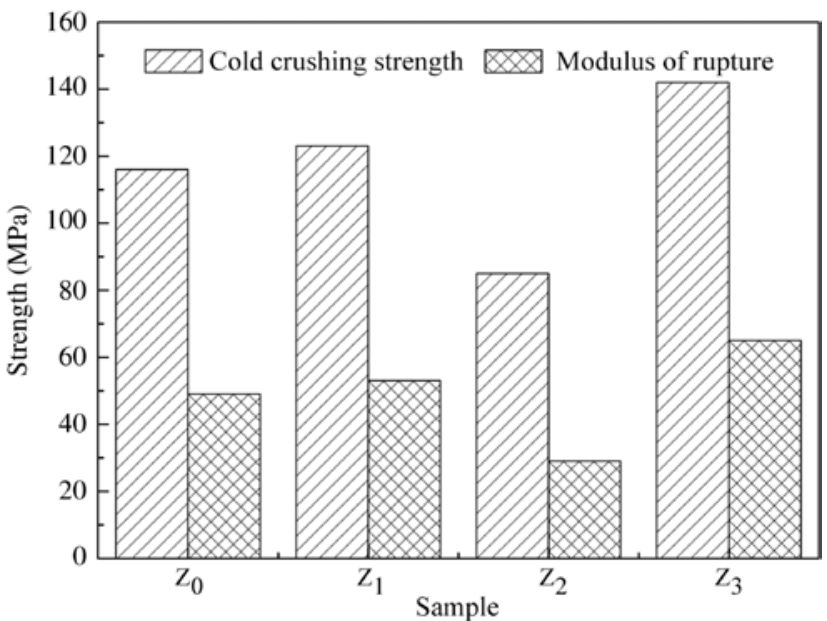

Figure 3 Cold crushing strength and modulus of rupture of samples.

$\mathrm{Al}_{2} \mathrm{O}_{3}$ ceramics. But there is only a negligible amount of $\mathrm{t}-\mathrm{ZrO}_{2}$ in the sample with $\mathrm{m}-\mathrm{ZrO}_{2}$ addition; thus, the slight enhancement of its room temperature strength can be explained by the dense structure. As shown in the marked area by the arrows in Figure $2 \mathrm{C}$, there is obvious defects in the sample with AZ40 addition, which lead to a decrease in room temperature strength of $\mathrm{Al}_{2} \mathrm{O}_{3}$ ceramics.

\subsection{Hot modulus of rupture}

Figure 5 shows the hot modulus of rupture of samples at $1400^{\circ} \mathrm{C}$. It can be seen that the addition of $\mathrm{m}-\mathrm{ZrO}_{2}$ or $3 \mathrm{Y}-\mathrm{ZrO}_{2}$ can improve the hot modulus of rupture of $\mathrm{Al}_{2} \mathrm{O}_{3}$ ceramics, the values of them are $20 \mathrm{MPa}$ and $22 \mathrm{MPa}$,

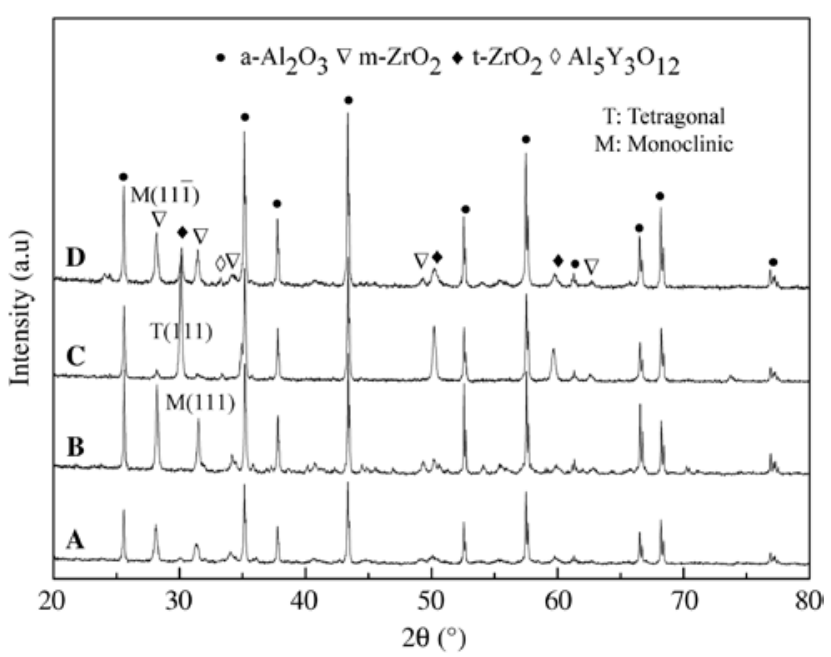

Figure 4 XRD patterns of the surfaces of samples (A) $Z_{1},(B) Z_{2}$, (C) $Z_{3}$, (D) $Z_{3}$ after the modulus of rupture test.

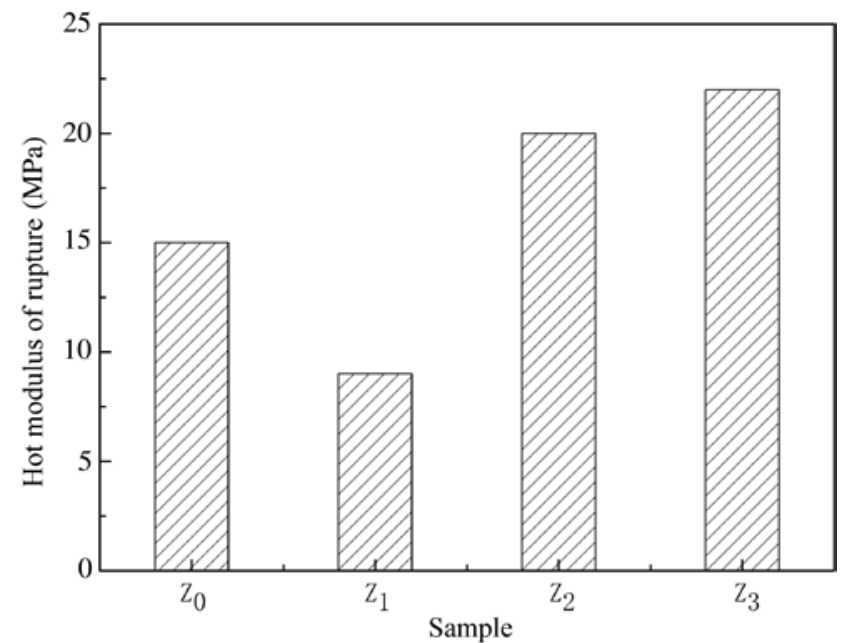

Figure 5 Hot modulus of rupture of samples at $1400^{\circ} \mathrm{C}$.

respectively, while that of the sample with AZ40 addition decreases to $9 \mathrm{MPa}$.

Some reports have pointed out that the principal factors influencing high temperature mechanical properties are the crystal effect and the glass effect $[17,18]$. In this work, there is practically no glass phase in the samples; the controlling factor is the crystal effect (degree and mode of contact or bonding between crystals).

Figure 6 shows the fracture surfaces of samples $Z_{1}, Z_{2}$, and $Z_{3}$ after hot modulus of rupture test. In comparison with sample $Z_{1}$, there are fewer gaps and pores between crystals in the sample with $\mathrm{m}-\mathrm{ZrO} \mathrm{r}_{2}$ or $3 \mathrm{Y}-\mathrm{ZrO}_{2}$ addition (see Figure 6C and D, respectively), indicating a strong interface between crystals. Moreover, the study on the bonding between $\mathrm{Al}_{2} \mathrm{O}_{3}-\mathrm{ZrO}_{2}$ by SEM and EDS shown in Figure 7 and Table 2 indicates that at the $\mathrm{Al}_{2} \mathrm{O}_{3}-\mathrm{ZrO}_{2}$ interface, there is interdiffusion at grain boundaries between the two phases. All these are important strengthening effects contributing to improvement of the hot modulus of rupture of $\mathrm{Al}_{2} \mathrm{O}_{3}$ ceramics. The SEM photograph of the sample with AZ40 addition shown in Figure 6A has a microstructure with large gaps and defects, the AZ40 particles grow during heat treatment to form larger particles with a diameter ranging from $8 \mu \mathrm{m}$ to $20 \mu \mathrm{m}$ due to the martensitic transformation of $\mathrm{ZrO}_{2}$, and even some $\mathrm{ZrO}_{2}$ particles drop out from the $\mathrm{Al}_{2} \mathrm{O}_{3}$ matrix in AZ40 particles (see Figure 6B). These defects result in a decrease in the hot modulus of rupture of $\mathrm{Al}_{2} \mathrm{O}_{3}$ ceramics.

\subsection{Thermal shock resistance}

The results of the thermal shock resistance of the samples are shown in Figure 8. As can be seen in Figure 8, the 

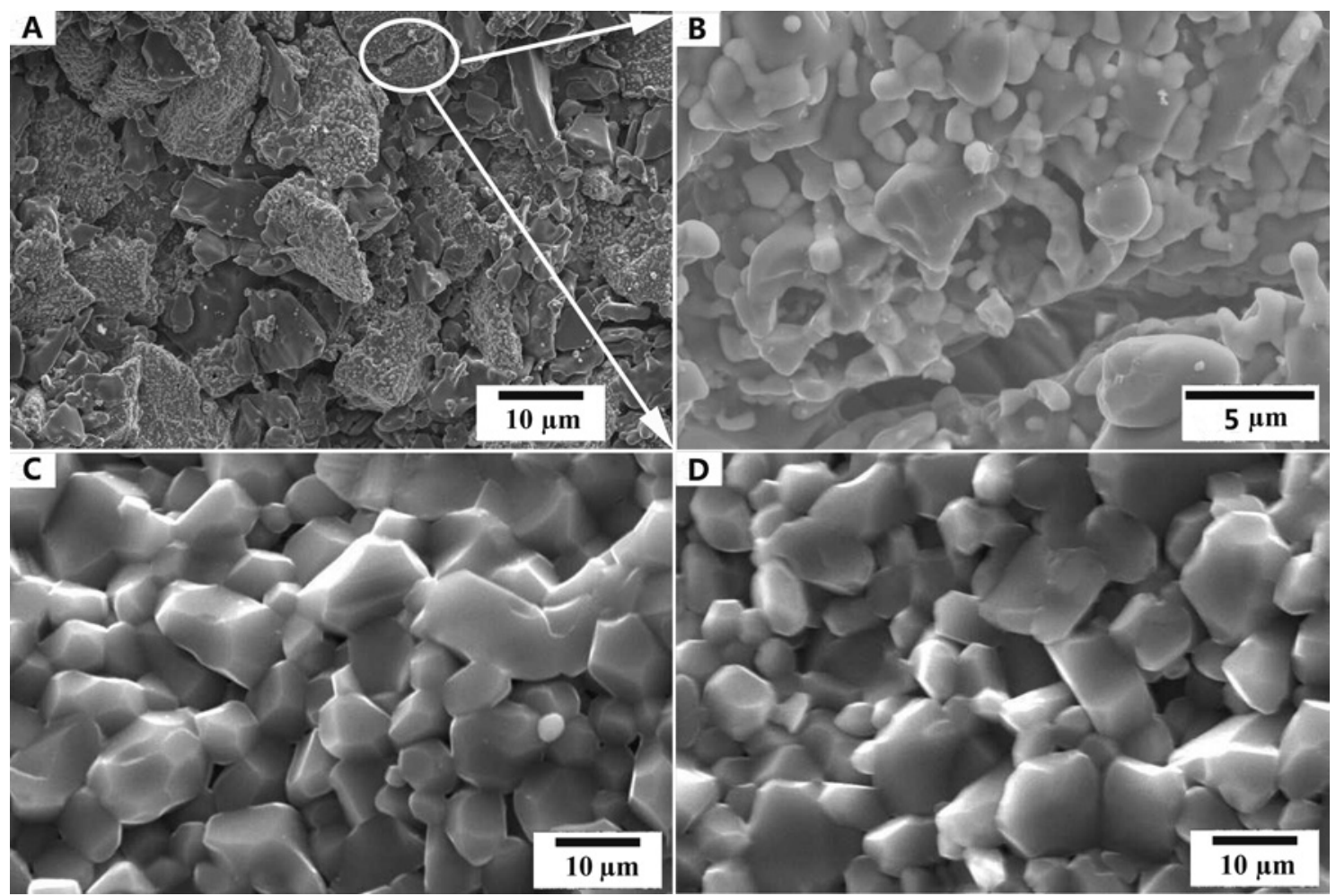

Figure 6 Fracture surfaces of samples $(A) Z_{1}$, (B) the magnification of the marked area in (A), (C) $Z_{2}$, and (D) $Z_{3}$.

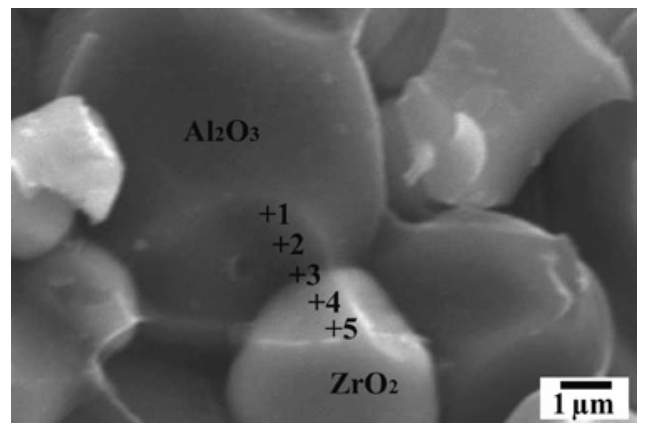

Figure 7 SEM photograph showing bonding between zirconia and corundum (the sample $Z_{3}$ ).

three kinds of $\mathrm{ZrO}_{2}$ are beneficial to improving the thermal shock resistance of $\mathrm{Al}_{2} \mathrm{O}_{3}$ ceramics, the residual strength ratios of samples $Z_{1}, Z_{2}$, and $Z_{3}$ are $62 \%, 68 \%$, and $71 \%$, respectively, and the maximum residual strength of $44 \mathrm{MPa}$ is achieved from the sample $\mathrm{Z}_{3}$.

Table 2 Composition of scanned sites of corundum and zirconia particles in Figure 7 by EDS.

\begin{tabular}{lrrrrr}
\hline Scanned site & $\mathbf{1}$ & $\mathbf{2}$ & $\mathbf{3}$ & $\mathbf{4}$ & $\mathbf{5}$ \\
\hline $\mathrm{Al}_{2} \mathrm{O}_{3}(\%)$ & 98.07 & 93.67 & 58.53 & 6.72 & 3.82 \\
$\mathrm{ZrO}_{2}(\%)$ & 1.93 & 6.33 & 41.36 & 93.06 & 95.93 \\
$\mathrm{Y}_{2} \mathrm{O}_{3}(\%)$ & - & - & 0.11 & 0.22 & 0.25 \\
\hline
\end{tabular}

In order to further evaluate the thermal shock resistance behavior, the microstructures of samples $Z_{1}, Z_{2}$, and $Z_{3}$ after thermal shock tests are examined, as shown in Figure 9. Some microcracks are observed on the surfaces of all the samples due to the spontaneous transformation of $\mathrm{ZrO}_{2}$, which can relax the stress concentration to enhance the thermal shock resistance of $\mathrm{Al}_{2} \mathrm{O}_{3}$ ceramics. In addition, for the sample with $3 \mathrm{Y}_{-} \mathrm{ZrO}_{2}$ addition, $\mathrm{t}-\mathrm{ZrO}_{2}$ can prevent crack propagation by compressive stress due to

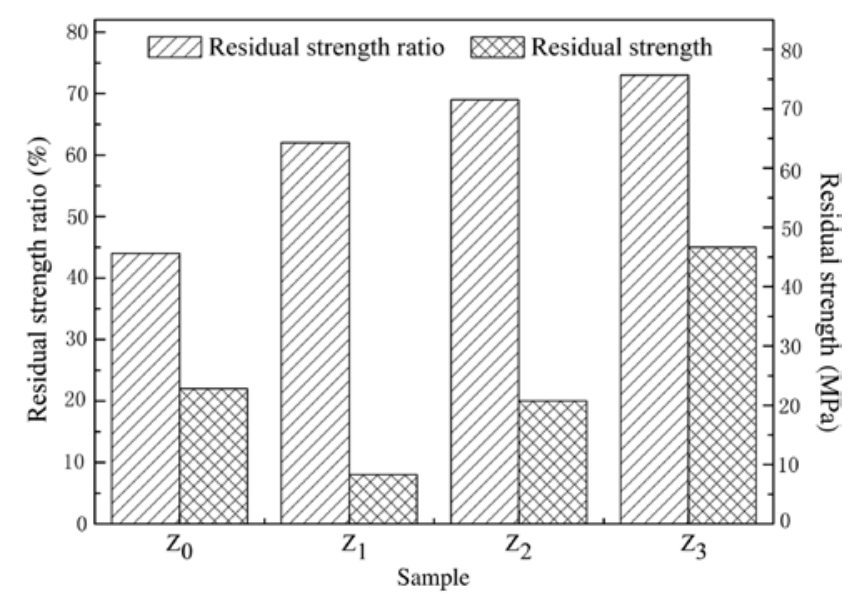

Figure 8 Residual strength ratio and residual strength of samples $\left(\Delta \mathrm{T}=1100^{\circ} \mathrm{C}\right)$. 

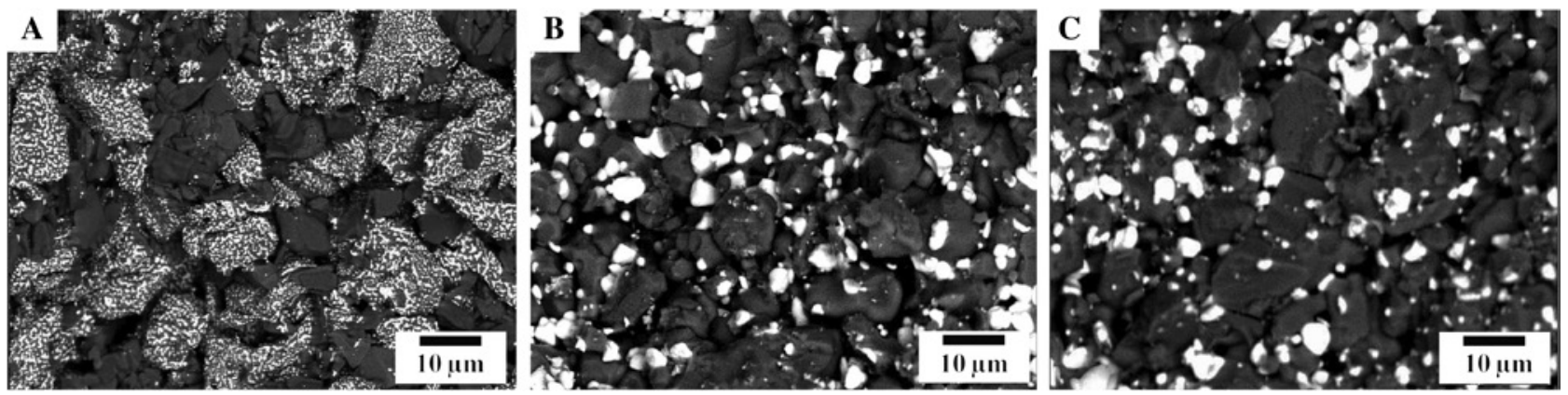

Figure 9 SEM photographs of samples $(A) Z_{1},(B) Z_{2}$, (C) $Z_{3}$ after thermal shock tests at $\Delta T=1100^{\circ} \mathrm{C}$.

the stress-induced phase transformation, which is beneficial to enhancing the residual strength of $\mathrm{Al}_{2} \mathrm{O}_{3}$ ceramics.

\section{Conclusions}

This paper compared the influence of $\mathrm{AZ40}, \mathrm{m}-\mathrm{ZrO}_{2}$, and $3 \mathrm{Y}-\mathrm{ZrO}_{2}$ on the properties and microstructure of $\mathrm{Al}_{2} \mathrm{O}_{3}$ ceramics. The main results obtained were summarized as follows:

1. $\mathrm{m}-\mathrm{ZrO}_{2}$ or $3 \mathrm{Y}-\mathrm{ZrO}_{2}$ addition promoted the process of sintering densification of $\mathrm{Al}_{2} \mathrm{O}_{3}$ ceramics due to the distributions of $\mathrm{ZrO}_{2}$, which inhibited abnormal grain growth of $\mathrm{Al}_{2} \mathrm{O}_{3}$ and led the dense structure, while AZ40 addition resulted in a volume expansion because of the phase transformation of the grown $\mathrm{ZrO}_{2}$ particles.

2. $\mathrm{m}-\mathrm{ZrO}_{2}$ or $3 \mathrm{Y}-\mathrm{ZrO}_{2}$ addition was beneficial to improving the room temperature strength of $\mathrm{Al}_{2} \mathrm{O}_{3}$ ceramics, and the effect of the latter was more distinct because of the stress-induced phase transformation toughening, while that of the sample with AZ40 addition decreased due to the defects in the sample.

3. The hot modulus of rupture of $\mathrm{Al}_{2} \mathrm{O}_{3}$ ceramics was enhanced by adding $\mathrm{m}-\mathrm{ZrO}_{2}$ or $3 \mathrm{Y}-\mathrm{ZrO}_{2}$, which was attributed to the enhancement of density and the interdiffusion at grain boundaries between $\mathrm{Al}_{2} \mathrm{O}_{3}$ and $\mathrm{ZrO}_{2}$ crystals, but that of the sample with AZ40 addition decreased.

4. The three kinds of $\mathrm{ZrO}_{2}$ were beneficial to improving the thermal shock resistance of $\mathrm{Al}_{2} \mathrm{O}_{3}$ ceramics because of the microcracks, induced by the martensitic transformation of $\mathrm{ZrO}_{2}$, which could relax stress concentrations and lead to toughening.

Acknowledgments: This work was supported by the Henan Research Program of Application Foundation and Advanced Technology (No. 122300410244), and the authors would like to express their appreciation to the High Temperature Ceramics Institute of Zhengzhou University for providing the necessary facilities during the experimentation and tests and also thank Dr. Huishi Guo, Dr. Zhen Ren, and Prof. Xinhong Liu for the helpful discussions and encouragements, and Prof. Enxia Xu and Prof. Quanli Jia for the assistance with the experiment.

\section{References}

[1] Rao PG, Iwasa M, Tanaka T, Kondoh I, Inoue T. Scr. Mater. 2003, 48, 437-441.

[2] Wahsh MMS, Khattab RM, Awaad M. Mater. Des. 2012, 41, 31-36.

[3] Maiti K, Sil A. Ceram. Int. 2011, 37, 11-21.

[4] Smuk B, Szutkowska M, Walter J. J. Mater. Process. Technol. 2003, 133, 195-198.

[5] Tuan WH, Chen RZ, Wang TC, Cheng CH, Kuo PS. J. Eur. Ceram. Soc. 2002, 22, 2827-2833.

[6] Jang HM, Cho SM, Kim KT. J. Mater. Sci. 1996, 31, 5083-5092.

[7] Zhang XF, Li YC. Mater. Des. 2010, 31, 1945-1952.

[8] Rittidech A, Somrit R, Tunkasiri T. Ceram. Int. 2013, 39, 433-436.

[9] Zu YF, Chen GQ, Fu XS, Luo KG, Wang CG, Song SP, Zhou WL. Ceram. Int. 2014, 40, 3989-3993.

[10] Ma WM, Wen L, Guan RG, Sun XD, Li XK. Mater. Sci. Eng. A 2008, 477, 100-106.

[11] Chen GQ, Fu XS, Luo JT, Zu YF, Zhou WL. J. Eur. Ceram. Soc. 2012, 32, 4195-4204.

[12] Zheng YT, Li HB, Zhou T, Zhao J, Yang P. J. Alloys Compd. 2013, $551,475-480$.

[13] Suffner J, Sieger H, Hahn H, Dosta S, Cano IG, Guilemany JM, Klimczyk P, Jaworska L. Mater. Sci. Eng. A 2009, 506, 180-186.

[14] Chen GQ, Zu YF, Luo JT, Fu XS, Zhou WL. Mater. Sci. Eng. A 2012, 554, 6-11.

[15] Kuo CW, Shen YH, Yen FL, Cheng HZ, Hung IM, Wen SB, Wang MC, Stack M. Ceram. Int. 2014, 40, 3243-3251.

[16] Xu YG, Huang ZH, Liu YG, Fang MH, Yin L, Guan M. Solid State Sci. 2012, 14, 730-734.

[17] Zhong XC. Sci. Press 1984, 13, 254-261.

[18] Zhong XC, Zhao HL. Bull. Acers 2000, 79, 59-61. 